\title{
Online Learning Environments and Some Pedagogical Implications
}

\author{
Maria de Fátima Goulão
}

Universidad Aberta, Dept of Education and Distance Learning, Portugal

\section{ARTICLE INFO}

\section{Keywords:}

Online Learning

Digital Skills

Pedagogy

E-Adults' Students

Higher Education

\begin{abstract}
Teaching and learning in digital environments have repercussions both in terms of pedagogy and the action of its agents, where digital skills are indispensable. It was based on these factors that we delineated, developed, implemented and accompanied a curricular unit within an online undergraduate course. We had basic assumptions, at a macro level, to respond to the expectations, needs, and objectives of that training offer; at a micro level, to provide the development of the competences, in the students, foreseen for the course unit. The design of this (UC), in an online system, requires knowledge, in addition to the domain of scientific content, concerning adult pedagogy and the way people integrate, remember and interact with information. The structuring of a course unit must respond to the needs and objectives of the e-student, to identify their expectations and needs, as well as to make the contents accessible for learning. We propose to present the methodology adopted, in the different phases of the design of a specific course unit (SLP). We have assumed, for this task, the ASSURE Model that proposes, as the last EVALUATE / REVISE phase. For this phase, we counted with the collaboration of 104 e-students, of both sexes and who attended this unit course. The data obtained point to a positive evaluation of the acquired competences, as well as the transfer of knowledge, acquired to other curricular units. The aspects related to the experience of the development of the unit course are also of positive evaluation.
\end{abstract}

\section{Introduction}

Online learning is increasingly being supported by educational and training institutions. The use of this type of education has had space in both non-formal and formal education institutions. We are talking about training and teaching in higher education institutions (initial and / or further training). There were many factors to which this contributed. The particularity of this resource has pedagogical repercussions leading to the need to rethink the contents, materials, evaluation, and development. All this taking into account a diverse audience, usually adult, with a personal and professional life that may be spread all over the world.

\section{The context}

We see that there is an increasing need for individuals to broaden their knowledge and acquire new skills. According to Askov et al. (2003) distance education have been identified as a possible means for adult students who cannot participate in face-to-face education programs and therefore do not participate in education programs, which involves classroom teaching. Technological developments have allied with this need and given shape to a new way of transmitting and receiving content to form individuals suited to the demands of the society in

* Corresponding Author E-Mail Address: fatimapgoulao@gmail.com 
which we live. Girardini (2011) defines e-learning as can be defined as the use of computer and Internet technologies to deliver a broad array of solutions to enable learning and improve performance (p. 3).

Online learning has gained popularity because it allows reconciling different aspects of an adult's life - family/work dimension. They can study in time and space as they see fit. Other needs make online learning a powerful ally, such as the geographical dispersion of individuals who do not have the resources to travel or individuals who have physical restrictions to follow their training in face-to-face education. As this is an adult audience, the pedagogical dimension of this type of audience needs to be taken into account.

Online teaching not only develops cognitive skills but also develops communication and interpersonal skills. This requires strategies that promote thinking skills, pointing to a more interactive scenario with a focus on "by doing". These scenarios can foster peer exchange and collaborative work by creating their learning networks. This depends on the objectives of the training and, in turn, on the way the course is planned. According to Brindley (2004),

Accordingly, studying at a distance requires maturity, a high level of motivation, the capacity to multi-task, goal-directedness, and the ability to work independently and cooperatively. (p. 287).

If we situate ourselves at the level of formal education environments, it is important to outline how we design training so that it is best suited to learning content as well as student characteristics.

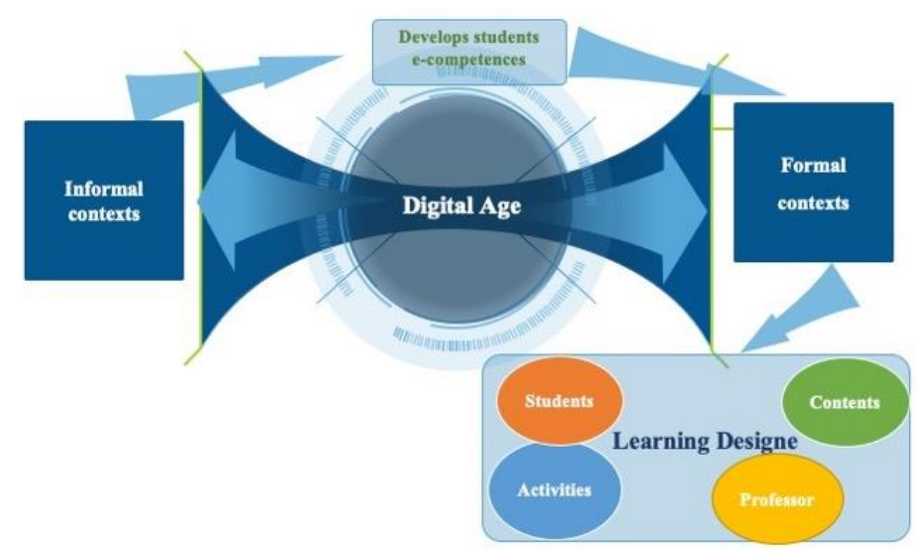

Fig. 1. Digital Age and Knowledge (source: the author)

In the past, we have seen the characteristics of a classroom teaching transposed into online teaching scenarios. However, these new learning scenarios have forced us to rethink the situation. And so we moved from teacher-centered teaching with static materials where no response was given to the individual characteristics of learners. That is, student learning styles should all be under the teacher's teaching style. Biškupić and Zorica (2012) state that the focus should be on active learning. For this to happen, the focus should be on student-centered learning. It is necessary to change strategies that lead to the autonomy of students for the development of critical thinking, with the support that leads to a debate of ideas, where there are negotiation and agreement on the objectives and the respective construction of knowledge, elements of active learning.

Biškupić and Zorica (2012) citing Chickering and Gamson (1997) indicate 7 principles that should be considered for good practice in undergraduate education.

- Encourage contacts between students and faculty,

- Develop reciprocity and cooperation among students, 
- Use active learning techniques,

- Give prompt feedback,

- Emphasize time on task,

- Communicate high expectations,

- Respect diverse talents and ways of learning. (p.3)

Virtual contexts of teaching and learning lead to a need to rethink both the planning, implementation and development of educational offerings. Instructional design has evolved significantly in recent years. Wen, et al. (2018) report that Instructional design frequently involves when instructional technology advances with new tools and ideas (p.10). However, these new tools should be selected by teachers and embedded in the course/course design considering the objectives set and should not constitute a barrier for students. New education scenarios imply new ways of teaching and learning in online contexts. The 'design' of the training program should include practice guidance, feedback to the students, the support that should exist for these students, thus lowering dropout rates.

The support and ability to motivate students in this type of learning is a very relevant factor (Goulão, 2019; Goulão \& Cerezo, 2016; Ubach \& Koning, 2016) since the relationship between - the face does not exist. Regarding the teacher this support and this increase in motivation can be done by feedback to the student's work, responding to the students' requests in a quick way, creating conditions that make the student know himself as such - create an environment that helps the student to reflect on how to learn and self-regulate (Goulão, 2019, 2012; Goulão \& Henrique, 2018). Anderson (2004) states that one of the first opportunities for teachers to develop their teacher presence (p.276) is in the design and construction of course content, learning and assessment activities. With this, we should not neglect the important role that support has among students.

Promoting student success by getting them to stay in the system and finish their education is a multidimensional factor in which 3 major dimensions (Askov et al., 2003; Seabra et al. 2014; Goulão et al., 2015) come together for that. One dimension concerns the characteristics of the student, the other is at the level of barriers external to the student and lastly, the characteristics of the teacher. The training of teachers to work in this education system is a factor to consider as it is necessary to develop skills that are suitable for online teaching. (Moreira et al. (2017); (Henriques et al., 2016a; Henriques et al., 2016b).

According to Goulão and Barros (2017) combined with these teaching-learning scenarios, from a formal point of view, both pedagogical approaches and learning materials must change. We find in virtual learning environments a panoply of supports to present the contents to learn. The flexibility in these environments promotes the use of different learning styles.

We have, therefore, associated with virtual learning spaces, we find three concepts adaptability, mobility, and cooperation. This means that in these educational contexts it is possible to respond more effectively to educational challenges by allowing the use of strategies and tools that best fit the needs and characteristics of students. In the concept of mobility, we find the flexibility that is experienced when searching for information in any space and at any time, freeing the learners from the constraints of space and time. Cooperation brings us to the possibility of building networks of work and knowledge between individuals who do not need to be physically present. This dual advantage - responding to individual needs and work for group organization - leads to the collective construction of knowledge.

It is in this context that Siemens (2004, 2005 and 2006) proposes a new theory of knowledge construction - connectivity. This theory was born from the combination of 3 areas education, technology, and innovation, focusing on the inclusion of technology. Our knowledge is based on the connections we create, either with other people or with sources of information, on the assumption that the student is the protagonist of their learning and the 
school has the role of facilitating the process of knowledge construction. So we have that in learning scenarios, in virtual contexts, this is not done linearly, but through connections within the network. According to Siemens (2005), learning is no longer an individual activity, although the starting point is always the individual. However, they do not live in isolation, but in a network that can be more or less extended. According to this author, in digital society, connections within the network lead learning. The keyword in this perspective is the connection. According to Siemens $(2005,2006)$ and Downes (2012), connectivism is the other theory of learning that allows learning to be explained in these non-linear social and interacting contexts of co-creation.

In brief, we can say that virtual learning scenarios promote mobility, ubiquity and now connectivity leading to reflection on the innovation of learning scenarios.

\section{The ASSURE Model}

Taking into account the theoretical framework developed above, it is appropriate, in this section, to make some considerations about the model that served as the basis for the construction of our course. The structuring of a course or course unit should be based on a course design system that will enable the training to be developed taking into account the learning objectives, their sequence, the strategies to be adopted and the way they are presented and, lastly the evaluation strategies. Girardini (2011), in this regard, refers to three aspects to be considered in course design (course unit)

- Instructional methods for e-learning;

- Delivery formats; and

- Evaluation methods. (p. 44).

At the time of the formatting of our course (teaching for the first time), one of the requirements was linked to the need to have the student as the center of the process, the acquisition of learning objectives and help reflect on their process of learning. Learning. After analyzing different models our decision fell on the ASSURE model.

The ASSURE model is an instructional system or guideline that teachers can use to develop lesson plans that integrate technology and media use (Smaldino et al. 2008). This model focuses on the learner and the overall outcome of the achievement of learning objectives to meet our needs. The acronym ASSURE represents the different elements/phases of the model that are represented in figure 2.

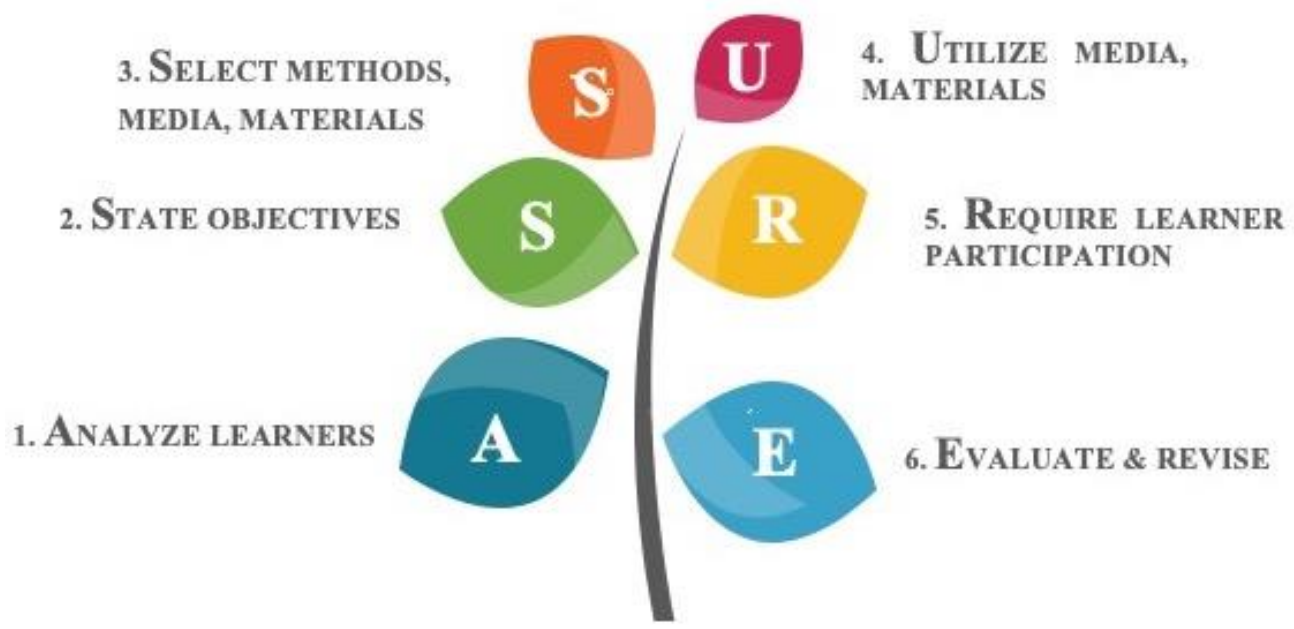

Fig. 2. ASSURE Model (Source: The own) 
The phases of this model take place at different times in the development/organization of training. That is, this model has a step by step approach. In table 1 we find the definition of each of these phases, as well as the moment when each one of them has its action.

Table 1.

What does it mean?

\begin{tabular}{|c|c|c|c|c|c|}
\hline 1. Analyze & $\begin{array}{l}\text { 2. State } \\
\text { objectives }\end{array}$ & $\begin{array}{l}\text { 3. Select } \\
\text { methods, } \\
\text { media, } \\
\text { materials }\end{array}$ & $\begin{array}{l}\text { 4. Utilize } \\
\text { media, } \\
\text { materials }\end{array}$ & $\begin{array}{l}\text { 5. Require } \\
\text { learners } \\
\text { participation }\end{array}$ & $\begin{array}{l}\text { 6. Evaluate \& } \\
\text { Revise }\end{array}$ \\
\hline $\begin{array}{l}\text { Who is the } \\
\text { audience? } \\
\text { *expectations, } \\
\text { goals, needs, }\end{array}$ & $\begin{array}{l}\text { What do } \\
\text { students need } \\
\text { to learn? } \\
\text { * Determine } \\
\text { the objectives }\end{array}$ & $\begin{array}{l}\text { What needs to } \\
\text { use for this } \\
\text { online context? } \\
\text { *Choose online } \\
\text { learning } \\
\text { contents, mídia, } \\
\text { exercises and } \\
\text { materials }\end{array}$ & $\begin{array}{l}\text { How do } \\
\text { instructors use } \\
\text { the materials? } \\
\text { * Decide how } \\
\text { utilize all the } \\
\text { instruments } \\
\text { most effectively. }\end{array}$ & $\begin{array}{l}\text { How to engage } \\
\text { students in this } \\
\text { context? } \\
\text { * Decide on } \\
\text { student } \\
\text { engagement } \\
\text { level. }\end{array}$ & $\begin{array}{l}\text { What works? } \\
\text { What doesn't? } \\
\text { How can I } \\
\text { improve? } \\
\text { * Evaluate and } \\
\text { review process } \\
\text { to ensure greater } \\
\text { success }\end{array}$ \\
\hline $\begin{array}{l}\text { Semester } \\
\text { Before }\end{array}$ & $\begin{array}{c}\text { Preparation } \\
\text { before } \\
\text { instruction }\end{array}$ & \multicolumn{2}{|c|}{ Instruction begins } & $\begin{array}{c}\text { During } \\
\text { instruction }\end{array}$ & End of semester \\
\hline
\end{tabular}

(Source: Adapted from https://idtassuremodel.wordpress.com/)

Interactive technology and media play an important role in shaping. However, this implies knowing how to use them, when to do them, and the strategies to adopt. One of the features of this model is the focus that is given to the design process itself and not just the result. We also found in this model a prior analysis of the students for which the training is intended. Only after this preparatory knowledge does it proceed to the next step/phase where the objectives to be achieved are defined. The ASSURE model has an emphasis on the use of technology. Thus, we enter the phase of selecting presentation modes or how content is conveyed. In this section, the model puts the possibility of using existing materials, with or without the need for modification for its purpose. Calling for student participation is also a requirement of the model. Finally, an evaluation is recommended at the end after the implementation of the previous steps. The objective of this phase is to learn from the difficulties that may have been encountered to guard subsequent formations.

In conclusion, the ASSURE model has six phases, each playing a relevant role for the success of the training: 1) Analysis of the participants (students); 2) Training objectives; 3) Selection of methods, media, and materials; 4) Use of materials and media; 5) promote student participation and, finally, 6) evaluate and review.

\section{A proposal}

We will now describe the context of our work, as well as our methodological options regarding the structuring of the curricular unit concerned. It will be designated for this SLP study.

In a narrower context, the course we are going to study is part of an online degree which, in turn, is part of the educational offer of a public distance learning university. The need to restructure the degree led to the rethinking of its curriculum. The curricular unit already existed, but a different approach was needed in terms of objectives, content, strategies, approaches and supporting materials. The new content has as objectives the knowledge of the learning process - the creation of objectives, goals, strategies, time management, procrastination, ... - at a macro level. At a micro level, reflect on their study and learning practices taking into account the aspects mentioned above, as well as the environment in which they are studying (Moodle virtual environment). To this end, students must understand the importance of the recursive 
cycle of self-regulation, as well as the importance of metacognition. Another point concerns the questions of plagiarism and the writing and referencing of academic works - Figure 3

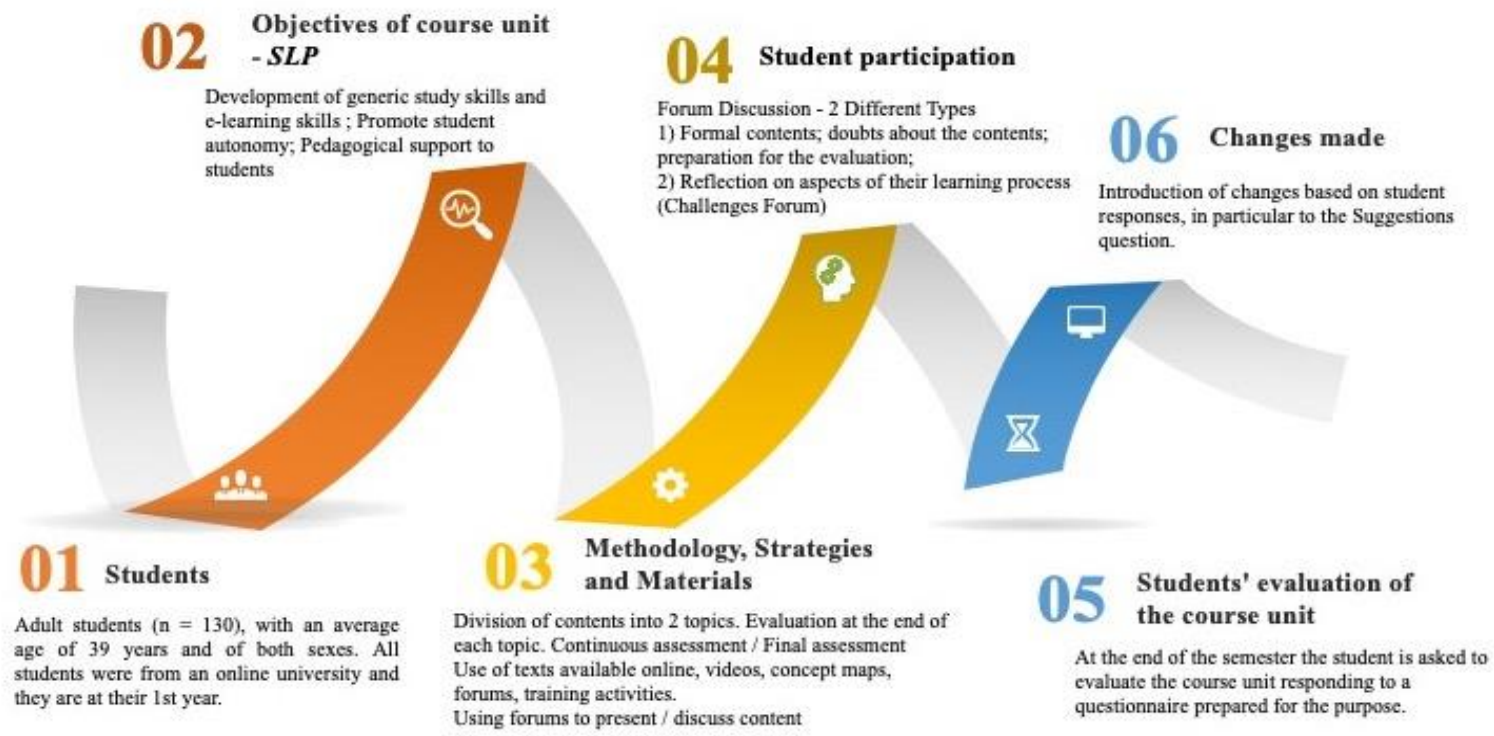

Fig. 3. Development of the course unit (Source: The own)

In the scope of methodology, strategies, and materials we tried to incorporate in the course a reflection on the contents per se and also how they were seen by students in their process. To achieve this last aspect and stimulate student participation, the following strategies were developed:

a) Creating a topic 0 where it subscribes,

b) The Forum of presentation and expectations regarding the curricular unit;

c) The possibility of answering questionnaires about self-regulation of learning and selfefficacy.

In the first main topic, in addition to the formal content and related forums, we designed a first forum called Challenges Forum 1. The first challenge addressed issues related to return to school. We recall here that these students are adults with a structured working and family life and for some reason had to interrupt their studies for a more or less significant time. Questions about setting learning objectives and the implications that may exist from being in a virtual environment are explored. Aspects related to study strategies, the self-regulation process and procrastination are also discussed. All this refers to the reflection based on each one as a student.

After the 1st assessment and after knowing their classification they were faced with a set of 3 questions that lead them to reflect on their study process. The introduction to them placed them in the cycle of self-regulation, as you can see,

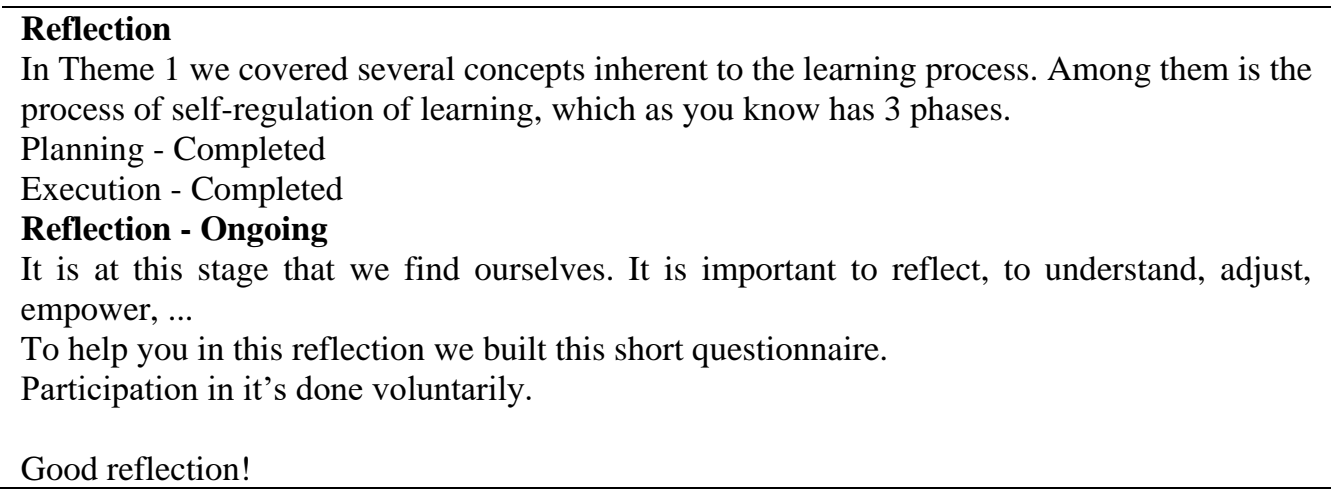


Q1. The rating I got matches what I expected...

Select an answer option:

a. True

b. False

Q2. How do you justify the classification obtained?

Q3. What do you intend to do to improve your performance in future work?

This format - Forum Challenges 2 and Reflection - was also used in main topic 2. Forum Challenges 2 dealt with questions about plagiarism, some aspects of study strategies (example - the importance of taking study material), profile and referral of the authors consulted to carry out academic work. Given that these are two "open" forums the issues that arise and which may vary from year to year. Although there is a basic structure, it must be sufficiently fluid to meet the needs of the students participating in them. Teacher presence is crucial in redirecting, challenging, helping students to self-explore their condition and thereby helping them become more autonomous in the learning process.

Finally, we have an evaluation of the curricular unit made by the students. A 3-part questionnaire was designed for this assessment. The first concerns the characterization of students. The second part concerns the evaluation of different course unit dimensions. Table 2 describes the different dimensions that make up this part.

Table 2.

Evaluation Dimensions (Source: The own)

\begin{tabular}{|l|l|c|}
\hline Dimension & This means & items \\
\hline $\begin{array}{l}\text { Dimension 1: } \\
\text { Content approach }\end{array}$ & $\begin{array}{l}\text { The evaluation of the forms and the means used to approach the } \\
\text { contents of the course unit }\end{array}$ & 7 \\
\hline $\begin{array}{l}\text { Dimension 2: } \\
\text { Usability }\end{array}$ & $\begin{array}{l}\text { Evaluation of how students perceive the exploitation of content in } \\
\text { different media to achieve their learning objectives. }\end{array}$ & 3 \\
\hline $\begin{array}{l}\text { Dimension 3: } \\
\text { Professor }\end{array}$ & $\begin{array}{l}\text { The evaluation of the teacher's behavior in the management of the } \\
\text { course unit and the effective monitoring of students. }\end{array}$ & 5 \\
\hline $\begin{array}{l}\text { Dimension 4: } \\
\text { Skills }\end{array}$ & $\begin{array}{l}\text { The evaluation of the contribution of the course unit to acquire } \\
\text { skills linked to a student's self-knowledge and their contribution to } \\
\text { improving their self-regulation }\end{array}$ & 5 \\
\hline $\begin{array}{l}\text { Dimension 5: } \\
\text { Knowledge } \\
\text { transfer }\end{array}$ & $\begin{array}{l}\text { The evaluation of the impact of the knowledge acquired in this } \\
\text { course unit in the approach to other curricular units }\end{array}$ & 3 \\
\hline
\end{tabular}

For the assessment of each dimension 1 question, a 4-point Likert scale has used that went from strongly disagree (1) to strongly agree (4). The third part concerns the general evaluation of the curricular unit. It is composed of three questions. Two intend to evaluate the students' experience in the curricular unit. For this, they had a Likert scale of 5 points [1 (Nothing important) to 5 (Very important)]. In the last question, we used the Free Word Association Test. We wanted students to define the curriculum unit using three keywords for them.

Based on the results of this questionnaire, some changes were made in terms of supporting materials and some strategies. We also promote the reinforcement of the teacher's role in accompanying and guiding students in their self-reflection.

\section{Conclusion}

Education and training have moved from a traditional classroom to a virtual environment thanks to the development of technology. These new scenarios have led to a change in the way training is designed and transmitted. This scenario implies systematic planning, organization, and development of training/education of the learning process (Ranaut, 2016). 
This paper aims to present our options regarding the structuring and development of a course unit in a virtual learning environment. For us, it was a challenge not only to select the topics that are part of it but also to make the student reflect on the contents based on his learning experience. This second part is something that we cannot overlook because student autonomy is an important factor for their academic success. This autonomy, which must exist in online environments, has effects on student motivation and self-regulation of learning. One explanation is that self-regulatory learning presupposes that students are active and control their learning processes. According to Pachler and Daly (2011) (...) self-regulation assumes the active participation of learners on those levels in their learning (p. 28). The teacher plays a crucial role in promoting self-regulating learning processes (Zimmerman, 2002). For this reason, we considered that knowledge of the self-regulatory system alone was not sufficient. It was our understanding that we should go further. That is, to allow students to learn about these mechanisms while incorporating them into their learning. The concept of self-regulating learning is used to describe how students consciously regulate their cognitive, metacognitive, motivation, and environmental strategies to achieve their goals (Zimmerman, 2002).

Concerning the environment, Aly (2004) (...) it is not the computer per se that makes students learn, but the design of the real-life models and simulations, and the students' interaction with those models and simulations. (p.3).

The environment where learning takes place is not the determining factor of the learning. This factor can be found in the way the course is delineated, in our case the course unit. This calls for materials that should be appropriate to the audience and the content for which it is intended, providing in-depth reflection but at the same time promoting the exchange of ideas with other students. To this end, interactive strategies should be devised that appeal not only to individual reflection but also to collaborative work and what Siemens calls co-creation. That is, activities that lead to the questioning of the contents should be outlined, providing a deep reflection on them.

Caplan (2004) tells us about the crucial role of the teacher (p.182). In addition to being the content 'expert', he/she should also be knowledgeable about the pedagogy best suited to this learning environment and thereby structure and develop training fostering effective and meaningful learning. This learning must include, on the one hand, the contents and, on the other, make the student aware of his way of learning. According to Carneiro (2003), the challenges that arise in the Knowledge and Learning Society relate to the knowledge management itself and the learning strategies.

(...) The most critical problem-solving competence that is so often spoken of in modern training taxonomies is that of solving their metacognitive equation. Thus, the new illiteracy will not be so much the absence of knowledge; it will mainly reside in the destitution of learning competencies (...) (p. 33).

In short, underlying the outline of this course unit were 2 major objectives - learning the content and awareness of the learning process. Despite the students' acceptance — reflected in their assessment - it is our understanding that a constant updating of materials and strategies is necessary, without neglecting the reinforcement in the student's awareness of his learning process. This will make students more autonomous and able to transfer this learning to the other courses' units.

\section{References}

Ally, M. (2004 ). Foundations of Educational Theory for Online Learning. In Anderson,T \& Elloumi,F (ed.). Theory and practice of online learning (pp. 3-32). Athabasca: Athabasca University 
Anderson, T. (2004). Teaching in an online learning context. In Richter-Z.O. \& Anderson, T. (Eds), Online distance education: Towards a Research Agenda (pp.271 - 294). Edmonton: AU Press, Athabasca University

Askov et al. (2003). Expanding Access to Adult Literacy with Online Distance Education. Cambridge: NCSALL

Biškupić, I \& Zorica, M. (2012). E-learning curriculum development. Available https://www.researchgate.net/publication/289419481_Elearning_curriculum_development

Brindley, J.E. (2004). Learner Support in Online Distance Education: Essential and Evolving.In Richter-Z.O. \& Anderson, T. (Eds), Online distance education: Towards a Research Agenda (pp.287- 342).Edmonton: AU Press, Athabasca University

Caplan, D. (2004). The development of online courses. In Anderson,T \& Elloumi,F (ed.). Theory and practice of online learning (pp.175-194). Athabasca: Athabasca University

Carneiro, R. (2003). Fundamentos da educação e da aprendizagem: 21 ensaios para o século 21. Vila Nova de Gaia: Fundação Manuel Leão

Downes, S. (2012). Connectivism and connective knowledge: Essays on meaning and learning networks. Available: http://www.downes.ca/files/books/Connective_Knowledge-19May 2012.pdf

Girardini, B. (2011). E-learning methodologies: A guide for designing and developing $e$ learning courses. Roma: FAO

Goulão, M.F. (2019). Student autonomy and metacognition in online learning. Proceedings of 9th International Conference the Future of Education. Florence, Italy, pp.108-112

Goulão, MF. \& Barros, D. (2014). Recursos educacionais abertos: estratégias, estilos e autorregulação da aprendizagem. In Moreira et al., A educação a distância e eLearning na web social (pp.129-152). Santo Tirso: De Facto editores

Goulão, MF. \& Cerezo, R. (2016). Promoting metacognitive reflection: a wok proposal. Proceedings of 2nd International Conference on Higher Education Advances, HEAd'16. València: Spain

Goulão, MF. \& Henriques, S. (2018). Estratégias de estudo e envolvimento dos estudantes em contexto de ensino superior online. In. Rigo, R. et al. Promovendo o engagement estudantil na educação (pp.83 - 102). Porto Alegre: EDIPUCRS

Goulão, MF. (2012). Ensinar e aprender em ambientes online: Alterações e Continuidades na(s) prática(s) docente(s). In Moreira, J et al. Ensinar e aprender online com tecnologias digitais - abordagens teóricas e metodológicas (pp.15-30). Porto: Porto Editora

Goulão, MF. et al (2015). Sucesso, permanência e persistência dos estudantes do ensino superior a distância online. Revista de estúdios e investigación en psicologia y educación. $1,1-28$.

Henriques, S. et $\mathrm{al}^{\mathrm{A}}(2016)$. Pedagogia em ambientes de aprendizagem em rede: $\mathrm{O}$ curso de formação para a docência online da Universidade Aberta. In Vieira, F. et al. Inovação pedagógica no ensino superior - Ideias (e) práticas, Vol.1 (pp. 105-118). Santo Tirso: De Facto editores

Henriques, S. et $\mathrm{al}^{\mathrm{b}}$ (2016). Respondendo aos desafios formativos da era digital: o curso de formação para a docência no ensino superior online. In Dias et al (org.). Novos olhares para cenários e práticas da educação digital (pp.149 - 159). Lisboa: Universidade Aberta 
Moreira, J. et al (2017). Digital Learning in Higher Education: A Training Course for Teaching Online-Universidade Aberta, Portugal. Open Praxis, 9(2), 253-263

Pachler, y Day. (2011). Key issues in e-learning-Research and practice. Nova Iorque: Continuum

Ranaut, B. (2016). Trends in Instructional Technology. Journal of Research \& Method in Education (IOSR-JRME), 6 (5), 16-22

Seabra et al (2014). Permanência da população adulta no ensino superior na modalidade de elearning -contributos para a sua compreensão, no caso da Universidade Aberta. In Aires et al. Educação a distância e diversidade no ensino superior (pp.19-26). Santo Tirso: De Facto Editores

Siemens, G. (2004). Connectivism: A learning theory for the digital age. Available: $\mathrm{http}: / / \mathrm{www}$.elearnspace.org/Articles/connectivism.htm

Siemens, G. (2005). Connectivism: A learning theory for the digital age. Available: http://www.elearnspace.org/Articles/connectivism.htm.

Siemens, G. (2006). Connectivism: Learning Theory or Pastime of the Self-Amused? Available: http://www.elearnspace.org/Articles/connectivism_self-amused.htm

Smaldino, S. et al. (2008). Instructional technology and media for learning. New Jersey: Pearson

Ubachs, G. \& Konings, L. (Coord.) (2016). Quality Assessment for e-Learning: a Benchmarking Approach (third edition). Heerlen: European Association of Distance Teaching Universities (EADTU). Available: http://excellencelabel.eadtu.eu/images/Excellence_manual_2016_third_edition.pdf

Wen, R. et al (2018). Re-envisioning an Instructional Design System for Higher Education: A Case Study for Online Course Curriculum Development. Hayward, CA: Office of the Online Campus, California State University, East Bay.

Zimmerman, B. J. (2002). Becoming a Self-Regulated Learner: an overview. Theory into Practice, 41(2), 64-70. 